\title{
Empirical Study of Specific Value Added Tax Problems in Selected European Union Member States ${ }^{\#}$
}

\author{
Danuše NERUDOVÁ ${ }^{*}-$ Petr DAVID ${ }^{* *}$
}

\section{Introduction}

The effort to harmonize the taxation systems within the European Union has been from the very beginning connected with the idea of the establishment of the Internal Market. The process of the Internal Market establishment subsisted mainly in the removing of the obstacles to the trade, which were represented by the different systems of the indirect taxation and different tax rates applied by the EU member states.

In the 1960s two systems of the indirect taxation were applied within the Europe. France was the only state applying value added taxation system and all the other member states were applying cumulative cascade tax system of the turnover tax. Except those two systems of general consumption tax, all the EU member states were applying also the systems of selective consumption taxes in the form of excise duties. As the European Commission wanted to harmonize the system of indirect taxation in the European Union as the pre stage of the establishment of the Internal Market, the main task of the European Commission in that time was to decide about the unified system of indirect taxation in the European Union.

\# This text is part of outcomes of research plan of Faculty of Business Administration of Mendel University of Agriculture and Forestry in Brno Czech economy in processes of integration and globalization and development of agrarian sector and sector of services in new conditions of European integrated market (registered number MSM6215648904).

* Ing. Danuše Nerudová, Ph.D. - senior lecturer, head of department; Department of Accounting and Taxes, Faculty of Business Administration, Mendel University of Agriculture and Forestry in Brno, Zemědělská 1, 61300 Brno, Czech Republic; $<$ d.nerudova@seznam.cz>.

** Ing. Petr David, Ph.D. - senior lecturer; Department of Finance, Faculty of Business Administration, Mendel University of Agriculture and Forestry in Brno, Zemědělská 1, 61300 Brno, Czech Republic; <david@node.mendelu.cz>. 
In 1960 the European Commission has appointed three working groups. The aim of working group I was to research the possibilities of harmonizing turnover taxes in the European Union. The working group was divided into subgroups A, B and C. Subgroup A has worked on the detailed study on the question of the possibility of the removal of the tax frontiers and the need of physical inspections at the border in relation to turnover taxes. The task of subgroup B was to consider the adoption of common single-stage general sales tax, which would be applied at a stage prior to the retail stage and if necessary, to consider the combination with the separate tax on retail sales. Subgroup C considered the possibilities of a common single-stage tax at the production stage with a separate tax at the retail stage if necessary. The results of the above mentioned working groups were later published as $\mathrm{ABC}$ report.

Furthermore, the Commission has also appointed Fiscal and Financial Committee to study the extent to which the applied indirect tax systems of EU member states conflicted with the establishment of the common market. The result of the Committee ${ }^{1}$ was that EU Member states must abolish the cumulative cascade tax and adopt value added tax instead. The report stated (for details see Thurston, 1963): “...cascade turnover tax causes distortion of competition within the national economics where it is applied and artificially promotes the concentration of enterprises, bit, in addition, it distorts the international trade regulations because of the impossibility of calculating exactly the overall charge of the turnover tax burden on the specific commodity and consequently, when the principle of country of destination is applied...."

Under the cumulative cascade system of turnover tax (in contrast to value added tax) the tax is levied on the gross amount (not value added) of the production at each production stage. Under the system of value added tax, tax is levied only on the value added (in contrast to cumulative cascade system). The system enables two possible principles of taxation as mentions (Nerudová, 2008). Under the principle of destination ${ }^{2}$ economical cooperation is needed otherwise the system could deform the market competition. Partly from the reason of the double taxation (in the case of goods delivered from the state applying the principle of origin - in the state of delivery the goods would be taxed for the second time

\footnotetext{
1 The report is known as Neumark report, for the Committee was chaired by Professor Fritz Neumark from Germany.

2 Goods and services are taxed in the state of consumption.
} 
according to the principle of destination) and partly from the reason of influencing competitiveness (in the situation when countries are applying different tax rates). From this reason the majority of the countries (according to $\mathrm{GATT}^{3}$ ) which are applying the principle of destination, exempt export from taxation and vice versa they tax import to eliminate double taxation. Under the principle of origin the goods and services are taxed in the country of their production. This principle is supposing the unified tax rates because the differences in tax rates can deform the market competition.

\section{Methodology}

Based on the tax theory, the system of indirect taxation should meet three basic criteria. Firstly, system of indirect taxation should not cause the market deformations. Secondly, the tax neutrality should be guaranteed. The last criterion represents the requirement, that the tax should be measurable in order to ensure proportional tax burden Kubátová (2006). Except the above mentioned basic criteria, the unified system of indirect taxation should also be easy to administrate - i.e. the administrative costs should be low. Moreover, the system should be able to tax all private expenditures - i.e. goods and services. Finally, system of the sales tax should also respect the basic rule of the tax theory - vertical and horizontal equity.

Under the system of cumulative cascade turnover tax is on every production or distribution stage paid certain percentage from the amount of the product as a tax (on the contrary to the VAT system, where the input and output taxable events are recorded). Even though the system seems to be easier from administrative point of view, there is one substantial imperfection. The cumulative cascade system of the turnover tax cause the market deformation, for the tax incidence is proportionally increasing with the length of production or distribution chain. Therefore the producer and distributors create integration for the final amount of the tax (tax burden) can be influenced by that. Under the system of cumulative cascade turnover tax the measurability is not guaranteed, for two identical products can comprise different amount of tax according to the length of the production or distribution chain.

3 General Agreement on Tariffs and Trade. 
Cumulative cascade system of the turnover tax faces also the problems with the equity. Under that system the vertical equity can be broken for two taxpayers in relatively same conditions can pay different amount of the tax for the consumption of the identical product (for the amount of the tax is dependant on the length of the distribution and production chain). On the contrary, the horizontally equity should be guaranteed for usually people who are better-off tend to consume more and therefore pay higher taxes, than the people relatively worse-off ${ }^{4}$.

To guarantee external neutrality in the system of cumulative cascade turnover tax is very difficult, for it is extremely difficult to determine the amount of the tax in case of export, for the identical products has undergone different number of production or distribution stages. The same is valid in case of the internal neutrality. It cannot be always guaranteed that the exports are exempted from the tax and the amount of the tax levied on the imports is the same as the amount of the tax levied on the domestic products. Neither the cumulative cascade system can ensure competitive neutrality, for the tax burden is dependant on the ratio of the vertical or horizontal integration. The only researched criterion, which can be fulfilled under the cumulative cascade system, is that it enables the taxation of all the private expenditures - goods and services.

Value added tax system on the contrary to the cumulative cascade system of turnover tax does not force the producers or distributors to the vertical or horizontal integration, for on each production or distribution stage is paid the same amount of the tax. Therefore, under that system also the equity and neutrality are guaranteed. It is also clearly measurable, for it is levied at each production stage only on the value added. The system also enables taxation of all private goods and services. The only criterion, which is not fully meet are administration costs, for they seem to be higher than in case of cumulative cascade system of the tax.

Based on the above mentioned findings, the European Commission agreed, that harmonization should proceed in three stages (David, 2007). During the first stage, member states should abandon their multi-stage

\footnotetext{
4 An extreme situation can arise in case that the people being worse-off would by the products with very long production and distribution chain while the people who are better-off would buy the products with very short production and distribution chain. Under that situation even that well-off people consume more, the worse-off people could pay higher tax because the effect of the increased tax due to the length of production (distribution) chain.
} 
cumulative turnover taxes and replace them by a non-cumulative system of their choice (first stage should finished four years after the implementation of the directive). During the second stage, noncumulative system should be replaced by a common value added tax system. Third and the final stage should result in the abolition of intraCommunity tax frontiers.

The first directive harmonizing the area of indirect taxation was directive No. 67/227/EEC adopted in 1967. It instructed Member States to replace the existing turnover tax systems by a common system of value added tax on the principle of general consumption tax, which is imposed on all goods and services and is set by the percentage of selling price and so it does not depend on number of the stages in production or distribution process. Tax rates and also tax exemptions were retained in the competency of the individual member states.

The second directive No. 67/228/EEC defined very clearly the definition of basic terms. The object of the taxation is the sale of goods and provision of services on the territory of the member state realized by the taxpayer, and the import of the goods. Further, the directive defined the place of fulfilment, taxpayers, sale of goods and provision of services. The member states were retained the right to adopted special provisions eliminating tax avoidances, the provisions setting special programme for small and medium sized companies and also this directive allows to set special programme ("fully corresponding to national possibilities and requests") for the agricultural sector.

The transformation of the taxation system and its implementation did not cause the difficulties in most Member States. Major difficulties were encountered in Belgium and Italy. In Belgium, it was particularly the fact that implementation of new system could cause the pressure on the budget expenditure. The above mentioned was the reason for adopting so called third directive No. 69/463/EEC, fourth directive No. 71/401/EEC and fifth directive No. 72/250/EEC were prolonging the time limit for VAT implementation in certain countries.

Structural harmonization is considered to be finished, by the implementation of the first and second directive. It was the first step in the process of the harmonization. The result of this step was not in any case the uniform system because directives allowed a wide range of the exemptions and differences (especially in the field of agriculture, cross- 
border provision of services or possibility of tax deduction from import). Instead of uniform system there was existence of nine individual systems with national differences.

In 1977, the sixth directive No. 77/388/EEC (Eur-lex, 1977) was adopted. The aim of the directive was to further harmonize the various national laws. It quotes the definition of tax base, the territorial reach, the subjects, tax rates and others. Abolition of the imposition of tax on importation and the abolition of remission of tax on exportation in the intra-Community commerce is generally considered to be the fact for the need of further harmonization. Another very important reason for further harmonization was the Council Decision No. 88/376/EEC, regarding the replacement of financial contributions from the Member States by the Community's own resources.

Sixth directive is considered to be the basic regulation in the area of indirect taxation harmonization; therefore it has been amended more than twenty times until now. To fulfil the aim of the European Commission, to make VAT legislative simple and transparent the directive no. $112 / 2006 /$ EEC was adopted. It represents the recast of the sixth directive - i.e. it comprises sixth directive with all other directives in frame of one text.

As mentions (Široký, 2007) the efforts to coordinate the VAT tax rates throughout the EU were completed in 1993. The directive No. 92/77/EEC stipulated the minimal limit for the tax rates. For standard rate the minimum of $15 \%$ was set and for reduced rate $5 \%$. Directive also allowed transitional period in which the member states could apply in the area of reduced tax rate the rate lower than $5 \%$.

It was necessary to use, during the elaboration of VAT application problems in case of providing services between the two subjects in one EU member states, in situation when the subject receiving the service further provides those services to the subject in other EU member state. The same problems are researched then in modification in which the provided services are connected with immovable property.

The research introduced standard methods of scientific work in frame of four selected EU states - Hungary, Slovakia, United Kingdom and Czech Republic. Method of the analysis is applied during the identification of characters of surveyed phenomena and method of 
synthesis for formulation of frameworks of unifying character in the final parts of the text. It was also necessary to use the method of description for description of the actual state of objective provision regarding given problems and other facts and phenomena in order to create essential connections based on processing and evaluation of relevant data. Among others the method of induction and deduction was used. The application of those methods enabled generalization of discovered facts and to formulate general valid principles including their supposed effects.

\section{Results}

Many harmonization successes have been achieved in the European Union during recent years within the framework of value added tax. The present situation can be probably described as satisfactory, especially in respect of the difficulty of promoting harmonization rules and in respect of considerable complexity of the rules which need to be revised, replaced or removed. Today, the greatest progress may be attributed to the consensus regarding changes of rules for determining the place of fulfillment in providing services, applying of "one-stop" mechanism for non-settled businessmen providing certain services and the overall modification of process of value added tax refund enabling the application of modern technologies. Specifically it concerns Council Directive 2008/8/EC of 12 February 2008 amending Directive 2006/112/EC as regards the place of supply of services (Eur-lex, 2008a), Council Directive 2008/9/EC of 12 February 2008 laying down detailed rules for the refund of value added tax, provided for in Directive 2006/112/EC, to taxable persons not established in the Member State of refund but established in another Member State (Eur-lex, 2008b) and Council Regulation (EC) No 143/2008 of 12 February 2008 amending Regulation (EC) No 1798/2003 as regards the introduction of administrative cooperation and the exchange of information concerning the rules relating to the place of supply of services, the special schemes and the refund procedure for value added tax (Eur-lex, 2008c).

However, there are at first sight some details, which are not treated at all or only insufficiently within the European Union. These details cause considerable confusion in value added tax application in more or less specific situations to which the concrete subjects liable to value added tax get into. Many problematic issues can be found in the field of providing 
services mainly because of their variability, rapid development and the resulting possibilities.

Fact that the service can be also provided further, brings confusion. As a starting point we consider the fact, that the provider of service shall provide a service to customer from other EU member state. Situation is further modified in such a way that the service shall be provided to a person from the same EU member state, which shall provide this service further to a customer from other EU member state.

\section{Fig. 1: Providing of services further to foreign person in the $E U$ states}

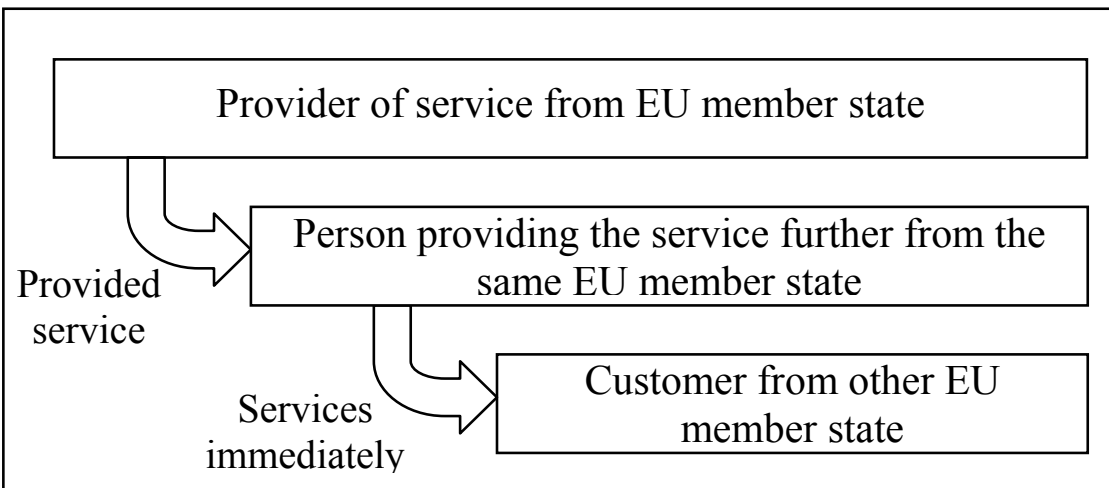

There is no longer clear, whether the provided service has changed its character, if it might have changed its character at all, if the place of the fulfillment of this service might have changed by the influence of its providing and what are the consequences for the stakeholders in the field of value added tax.

Services connected with immovable property provided in such a way are considered to be a problematic point in frame of services provided between subjects from various EU member states. It concerns the services provided by provider from one EU member state to recipient of the service from other EU member state, where such services are connected with immovable property situated in the state of the provider. 


\section{Fig. 2: Providing services connected with immovable property in EU} member states

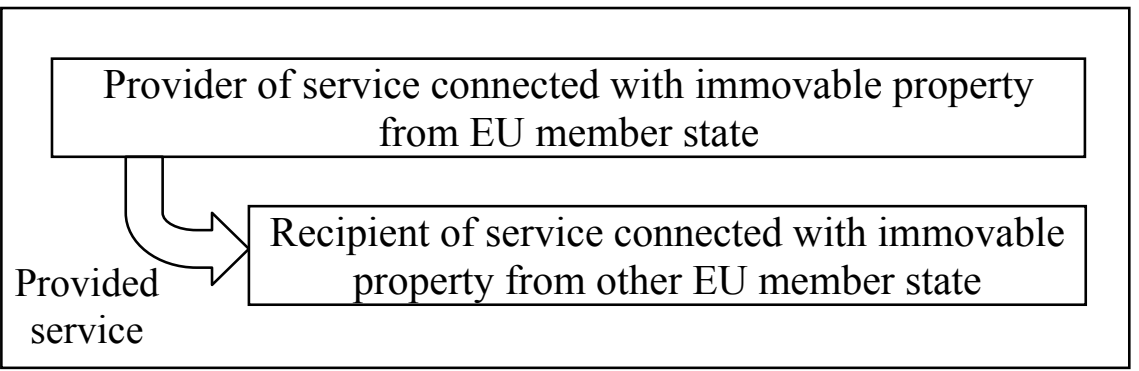

The subject from EU member state provides a service connected with immovable property situated in the country of provider to a recipient who is registered for value added tax in other EU member state. The question is, whether there is binding or non-binding list of services connected with immovable property within the meaning of Article 45 of Council Directive 2006/112/EC of 28 November 2006 on the common system of value added tax (Eur-lex, 2006), which states that the place of provision of services connected with immovable property, including services of real estate agents and experts and services in the preparation and coordination of construction works, such as architects services and construction supervision services, is the place where the immovable property is located. Uncertainties may also arise when the services connected with immovable property situated in one EU member state shall be provided on name or on behalf of another person registered for VAT in other EU member state.

In such situations the possibility of differences in the various countries of the European Union should be taken into account. The possibility of differences is the fundamental fact which limits the conditions of free trade within the European Union, and must be therefore urgently solved. Solution must be firstly based on a thorough analysis of the current situation in EU member states. Further there is also a need to formulate proposals for appropriate regulations, from which subsequently shall be selected the appropriate one. Consequently, it is necessary to implement regulations through releases of the relevant directive. It is also necessary to monitor the application of the given regulation in EU countries and eventually carry out further changes on the basis of feedback. 
Three new EU member states - namely the Czech Republic, Slovakia and Hungary and one traditional EU member state - United Kingdom, were selected in order to research the given issue. The fact, that all concerned subjects are VAT payers is considered to be an essential prerequisite.

Firstly, the situation, when the service is immediately provided further by a subject from the Czech Republic to a provider also from the Czech Republic, which shall immediately provide service further to a customer for example from Slovakia, is researched.

\section{Fig. 3: Providing service immediately further to foreign entity -} Czech Republic

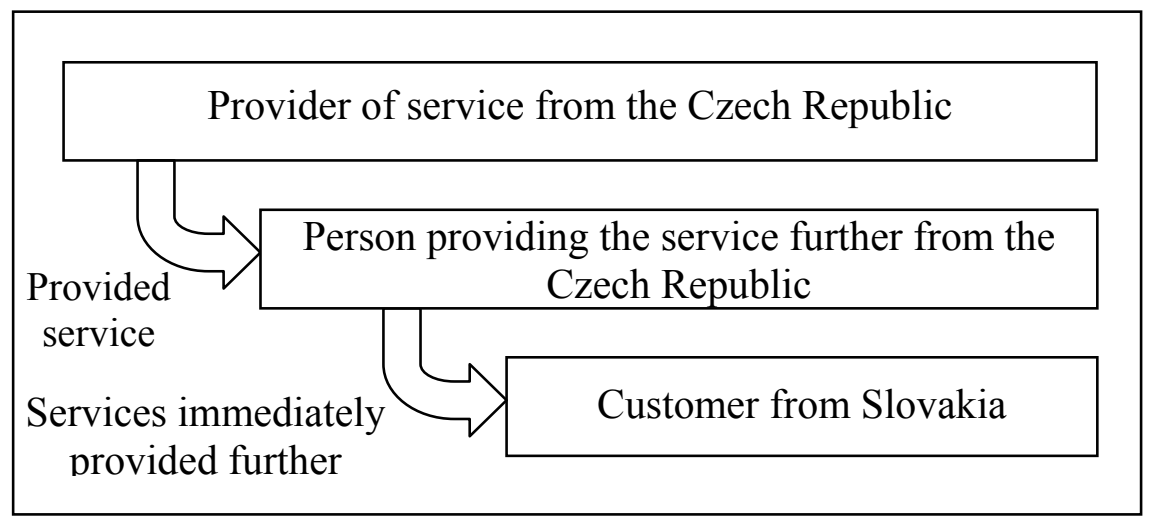

Providing service immediately further itself is not clearly defined and legally treated in the Czech Republic. In general, it is possible to say that providing service immediately further to the customer in the Slovakia does not change the substance of provided service. For example during purchase of consulting service by a subject in the Czech Republic from the subject from the same country and by the consequent providing service immediately further and by the use of service by customer in Slovakia, this fulfillment remains consulting services. This fact is generally accepted and it is also accepted by the Ministry of Finance of the Czech Republic. It is necessary to strictly monitor, whether this service is not part of another fulfillment during providing service immediately further.

Providing taxed service immediately further according to the scheme is not subject to the Czech value added tax under Czech Act No. 
235/2004 Coll., on value added tax, but only in the case, when the provider shall not claim value added tax on input from this provided service and shall provide it without a margin. If a person providing the service further to Slovakia is applying value added tax on inputs from provided service immediately further or he adds margin to its price, then this service with the place of the fulfillment in the Czech Republic shall become taxable fulfillment.

In providing services immediately further exempted from value added tax to Slovakia under Czech Act No. 235/2004 Coll., on the value added tax, and in providing services further without margins, this provision further is also exempted from value added tax. However, in the opposite case it is evident, that it is a service with the place of the fulfillment in the Czech Republic which is liable to VAT.

It is evident from the above mentioned facts, that the regulation of providing service immediately further is not in accordance with the Sixth Council Directive 77/388/EEC of 17 May 1977 on the harmonization of the laws of the Member States relating to turnover taxes - Common system of value added tax: uniform basis of assessment (Eur-lex, 1977), in the Czech Republic. This fact is also obviously the cause of the difference in regulation of providing services immediately further in the Czech Republic in comparison with other EU countries.

How is the situation in the Czech Republic in terms of value added tax in case of provision of service by a subject from the Czech Republic to a recipient of service from Slovakia, where such services are connected with the immovable property situated in the Czech Republic?

Fig. 4: Providing services connected with immovable property Czech Republic

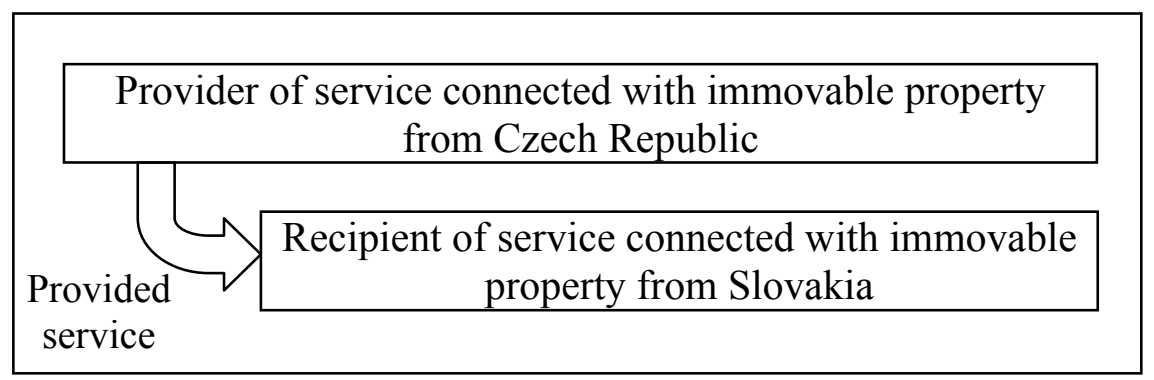


There is no binding list of services related to immovable property in the Czech Republic. However, the Ministry of Finance of the Czech Republic released at least non-binding information in the sense, that ECJ case C-166/05 Heger Rudi should be followed. According to the judgment (Eur-lex, 2005), services are considered to be connected with immovable property, if the services have a sufficiently direct connection with immovable property. Sufficiently direct connection means that the property is a central and indispensable element of the fulfillment. In practice, there is an interpretation that direct connection between the service and property exists if the service is connected with specific property.

Services provided on a name or on behalf of third parties registered for VAT in other EU member state may be subject to self-assessment. However, this rule is not applicable in all situations. In these specific situations, the service is not connected with immovable property. Services connected with immovable property situated in the Czech Republic may be therefore subject to self-assessment in Slovakia, if they have been provided on a name or on behalf of third parties registered for value added tax in Slovakia.

Situation of providing services immediately further by a subject from Hungary to person providing the service further also from Hungary, which shall provide this service immediately further to a customer for example from the Czech Republic is also interesting.

\section{Fig. 5: Providing services immediately further to a foreign person -} Hungary

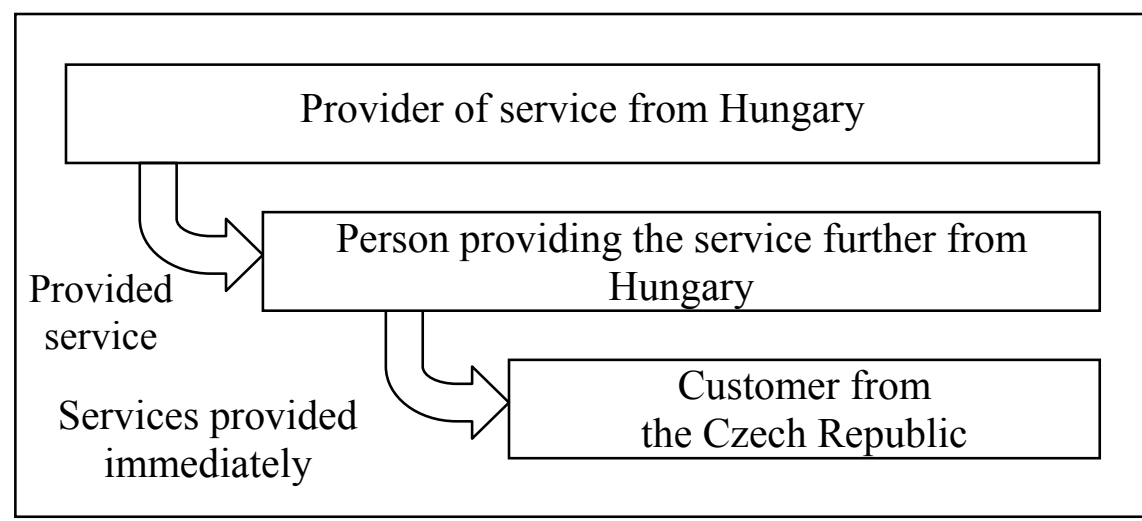


As part of the Hungarian regulation of value added tax, there is no concept of provision of service further at all and so it is clear that this situation is also similar in case of provision of service further to foreign person. The best possible way, how to cope with further provided services in terms of value added tax is simply to consider it to be only the service provided. This seems to be at first sight, simple and smooth solution of value added tax in frame of services provided immediately further, however, it brings number of questions, that are dealt in the practical situations, particularly intuitively, or based on the recommendations of other subjects in Hungary, which already came with the situation into contact.

Place of the fulfillment in providing service immediately further provided by a subject from Hungary to a person providing the service further also from Hungary, which will provide this service further to a customer from the Czech Republic, is the same as in case of traditional providing services. However, there remains the question in this situation, who is the real customer in the whole transaction. Is it a person providing the service further from Hungary or customer and the real recipient of provided service further from the Czech Republic? The practical experience has brought two options during determining the date of the fulfillment of service provided immediately further. Either the date of the fulfillment of provided service further is identical to the original date of provided service or maybe it is possible to submit corrective tax return with the date of provision of service further.

In the case of provision of services connected with immovable property by a provider from Hungary we consider a person from Czech Republic as the recipient of the service. The property is situated in Hungary, in the country of provider of the service.

In Hungary, there is no binding list of services connected with immovable property, there is only a non-binding list. Services connected with immovable property are here defined as services of real estate agents and professionals and services associated with the preparation and coordination of reconstruction works on the immovable property. These services do not include, for example, engineering services, which are regulated separately from services related to immovable property. 
Fig. 6: Providing services connected with immovable property Hungary

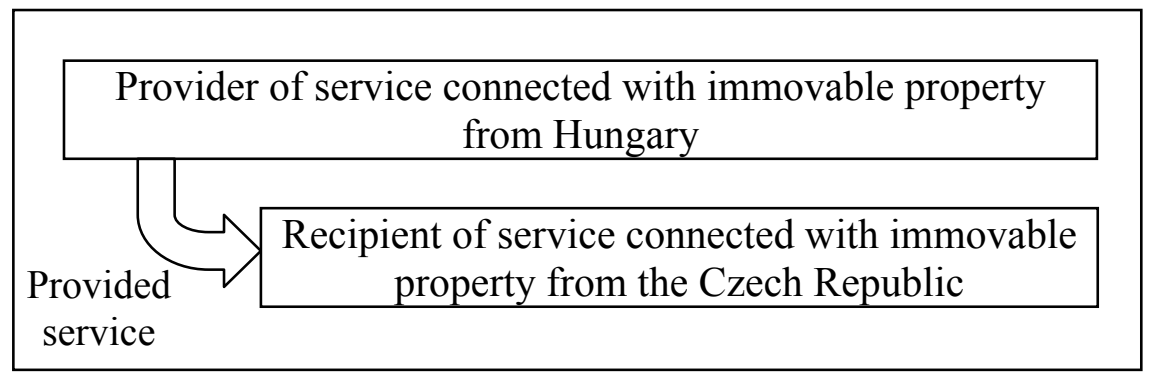

In the provision of services connected with immovable property by a provider from Hungary to a recipient of service from the Czech Republic, the place of fulfillment is Hungary and the person providing the service is applying the Hungarian value added tax. Services connected with immovable property situated in Hungary may be under Hungarian law subject to self-assessment in the Czech Republic, if they are provided on name or on behalf of third parties registered for value added tax in the Czech Republic.

In Slovakia, the regulation of services immediately provided further by a subject from Slovakia to a person providing the service further also from Slovakia, which shall provide this service immediately further to a customer for example from Hungary, is significantly different from regulation in mentioned countries so far.

Fig. 7: Providing services immediately further to a foreign person Slovakia

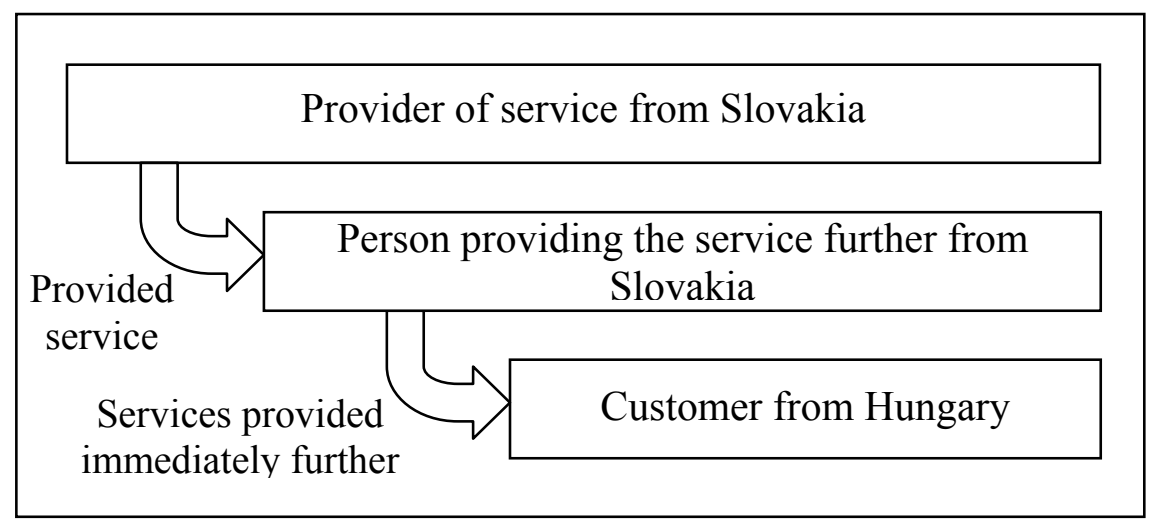


If a person providing service further from Slovakia acts on its own name, then this person is considered to be the recipient of the service and the provider of service as well. This way of solution of the given situation corresponds to Article 28 of Council Directive 2006/112/EC of 28 November 2006 on the common system of value added tax (Eur-lex, 2006), which states that where a taxable person acting in his own name but on behalf of another person takes part in a supply of services, he shall be deemed to have received and supplied those services himself. Therefore, it may also happen that the provided service further may lose the character of exempted service, as for example postal services or medical care in Slovakia. However the fact that it is a service does not change in frame of provision of service further.

In the case that person from Slovakia who provide the service further acts on behalf of a customer from Hungary, then the person providing the service further does not include financial sources to value added tax base. Solution of this situation in Slovakia therefore corresponds to Article 79 (c) of Council Directive 2006/112/EC of 28 November 2006 on the common system of value added tax (Eur-lex, 2006), which states that The taxable amount shall not include the amounts received by a taxable person from the customer, as repayment of expenditure incurred in the name and on behalf of the customer, and entered in his books in a suspense account, and that the taxable person must furnish proof of the actual amount of the expenditure and may not deduct any VAT which may have been charged.

Date of making out an invoice by a person providing the service further is the relevant date of fulfillment of provided service further by a person providing service further from Slovakia to a customer to Hungary.

In case of provision of services connected with immovable property by a provider from Slovakia, we consider a subject from Hungary as the recipient of the service. The property is situated in Slovakia, i.e. in the country of provider of the service.

Neither in Slovakia there is a binding list of services connected with immovable property. However, there is a rule issued by the Financial Directorate in Slovakia, where some specific cases with their subsequent connection to the case law of the European Court of Justice (e.g. C166/05 Heger Rudi) are introduced. Another rule of Slovak Finance Directorate regarding services provided by the mediator shows, that if it concerns the service connected with the immovable property, the place of 
fulfillment is the place, where the property is situated, in our case in Slovakia.

\section{Fig. 8: Providing services connected with immovable property -} Slovakia

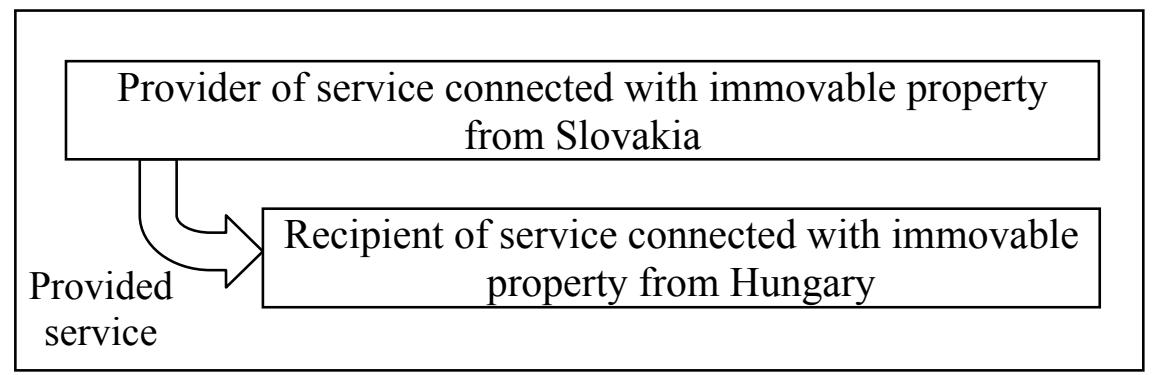

Finally, we solve the situation, when the service is provided immediately further by a subject from United Kingdom to a person providing the service further also from United Kingdom, which shall provide this service immediately further to a customer for example from the Czech Republic.

Fig. 9: Provision of services immediately further to foreign person United Kingdom

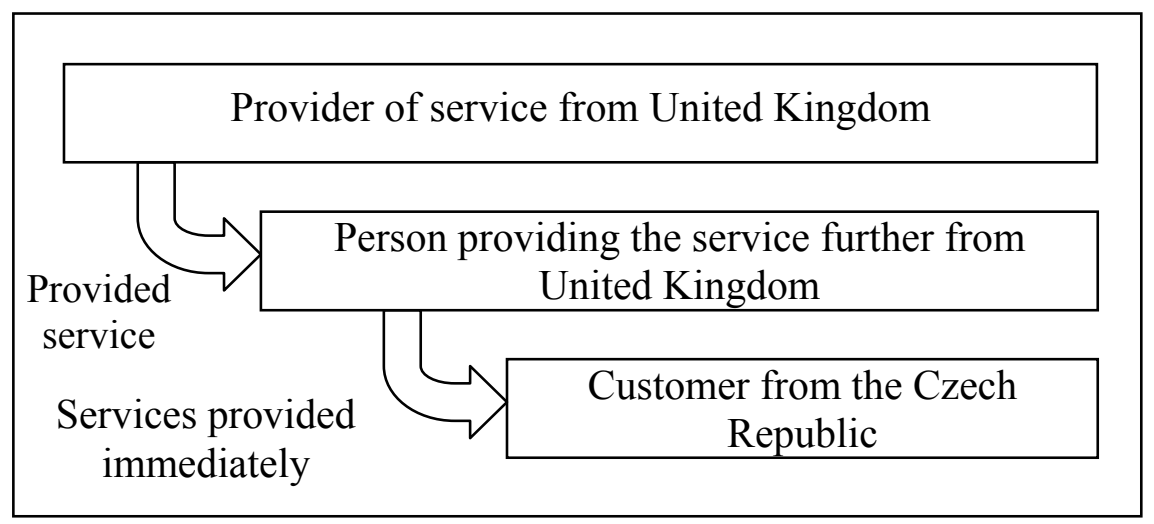

The regulation of the value added tax in United Kingdom in particular makes a difference between repayment of expenditure and real provision of services immediately further. The differences between repayment of expenditure and provision of services immediately further are therefore following. 
Repayment of expenditure is defined as incurring the expenditure for another person and it is proceeding - i.e. as if no fulfillment has been adopted. Person providing the service further from the UK to a customer in the Czech Republic can not claim the right to deduct the value added tax on input. Person providing the service further from the UK to a customer in the Czech Republic does not consider provision of service further as a provided fulfillment.

Provision of service further is not considered to be a fulfillment in the UK. Person providing the service further from United Kingdom provide service (by contract) to a customer from the Czech Republic only through request to a provider of service from United Kingdom to provide the service. In providing service immediately further in the UK it is very unusual that although the provision of services in the described way is apparently directly between the provider of service from United Kingdom and the customer from the Czech Republic, fulfillment for VAT purposes in the UK exists both between provider of service from the UK and person providing service further from United Kingdom and as well as between this person providing service further and customer from the Czech Republic.

The nature of the service provided immediately further usually does not change in the UK, however, also this situation can take place according to practical experience of the subjects.

In the provision of services connected with immovable property by a provider from United Kingdom we consider the person from Czech Republic as the recipient of this service. The immovable property is situated in United Kingdom.

Fig. 10: Providing of service connected with immovable property United Kingdom

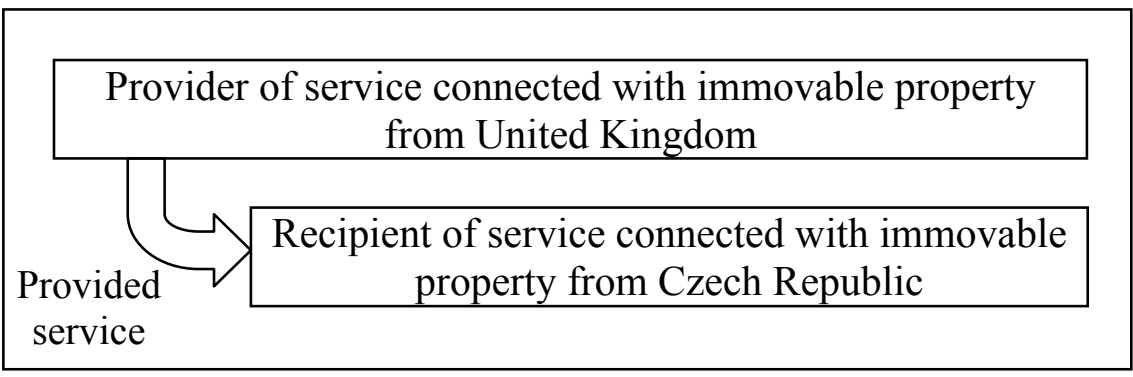


Neither in Great Britain there is the binding list of services connected with immovable property. Service remains tied to given immovable property and it is necessary to apply the UK value added tax in providing services on behalf of a third party. Provider outside the United Kingdom providing services relating to immovable property situated in the UK can avoid registration for the UK value added tax, if the customer from the Czech Republic is registered for the UK value added tax and is applying value added tax through the mechanism self-assessment. The existence of a link of service with a specific immovable property is fundamental in the UK.

\section{Conclusion}

It is necessary to realize following steps, needed for achieving of higher level of harmonization in the filed of value added tax, which shall contribute to reduction of barriers of free trade and to its development on the EU market. Firstly, the problematic points in the individual EU states had to be defined and these points on the base of primary and wide discussion resulting in general consensus accordingly modify through issuing of appropriate directives. These rules already exist and now this is the period of implementation of modifications into the national systems of value added tax in the individual EU member states. It is necessary to proceed a number of modification in frame of providing services. Based on the results of the research done in the paper, providing service connected with provision of this service further to a foreign person and providing service connected with immovable property is not sufficiently treated according to previous study in the EU states.

There are general insufficiencies and also individual problems in EU member states. Whole absence of provision of service further or only not clear definition of provision of service further or obscurities in term of change of nature of service, which we can consider as system insufficiencies belonging to general insufficiencies in term of provision of service further to a foreign person. The situation in the Slovakia is almost clear, where the regulation de facto corresponds to rules of the EU. Acting on own name and on behalf of customer is distinguished here and treatment of valued added tax then corresponds to it. Repayment of expenditure and providing service further is distinguished in the United Kingdom. It is possible to see insufficiencies mainly in uncertainties regarding changes of nature of some provided service further to a subject 
in other EU member state. In the Czech Republic, even the new regulation is being prepared, the state does not corresponds to the Sixth Council Directive 77/388/EEC of 17 May 1977 on the harmonization of the laws of the Member States relating to turnover taxes - Common system of value added tax: uniform basis of assessment (Eur-lex, 1977). However, it is obvious, that the nature of service in its providing service further to a person from other member state does not change. In Hungary, there is evident overall absence of concept of providing service further, so obscurities arise in any presence of provision of service further to a subject to other EU member state. Now the situation is solved in such a way, that persons meeting providing service further have to try to follow practical experience of other subjects.

In the field of providing service further by a person providing the service further from the state of provider of service to a customer from other EU member state it is necessary mainly to adapt national legislations of EU member state to requirements of directives dealing with the given issues. Further, all attributes regarding provision of service further have to be defined (at the European level) and set the conditions of relevant options of changes of character of service and the place of the fulfillment connected in its providing service further.

Mainly the absence either of any specification of service, which may be connect with immovable property or absence of such specification in the binding form is general problem in term of provided services connected with immovable property to other member state. ECJ case law regarding given issues is often applied in the practice, however, it is not possible to apply it on all situations resulting during the providing services connected with immovable property. Generally, it may be said, that in the researched states the link of service with concrete immovable property is essential, in more moderate form for example in the Czech Republic, at least link with project, in the strict form for example in Hungary. It is needed to document everything also by study of practicability. It is possible to apply institute of VAT self-assessment in providing service connected with immovable property situated in the given EU member state provided on the name and on the account of third person registered for VAT in other member state in all given EU member states without significant difficulties, but with certain limitations.

It is possible to recommend mainly at the EU level to formulate binding list of services which is possible to connect with immovable 
property in frame of providing service connected with immovable property situated in the state of provider of provided service to other EU member state. In completing of this list it is necessary to respect already existing lists in the individual EU member states and also the rules applied in practice in given field. Further, it is necessary to set, whether it is possible to connect service with not existing immovable property, for example on the base of project, or whether it would not be suitable on the contrary to require already mentioned study of practicability.

After the formulation of the above mentioned points, it is necessary to pay attention to timed and rigorous application of adopted rules in the individual EU member states. Acquisition of feedbacks from the state applying appropriate regulation, its evaluation and eventually discussion and modification of identified problematic parts are also essential.

\section{References}

[1] David, P. (2007): Theory of tax incidence with practical aplication. (in Czech: Teorie daňové incidence s praktickou aplikaci.) Brno, CERM, 2007.

[2] Eur-lex (1977): Sixth Council Directive 77/388/EEC of 17 May 1977 on the harmonization of the laws of the Member States relating to turnover taxes - Common system of value added tax: uniform basis of assessment. [on-line], Luxembourg, Office for Official Publications of the European Communities, c2008, [cit. $5^{\text {th }}$ September, 2008], <http://eur-lex.europa.eu/LexUriServ/LexUriServ. do?uri=CELEX: 31977L0388:EN:html>

[3] Eur-lex (2005): Judgment of the Court (Third Chamber) of 7 September 2006. Heger Rudi GmbH v Finanzamt Graz-Stadt. Reference for a preliminary ruling: Verwaltungsgerichtshof Austria. Sixth VAT Directive - Place of supply for tax purposes Article 9 - Supply of services connected with immovable property Transmission of the fishing rights over a particular part of a stretch of water. Case C-166/05. European Court reports 2006 Page I07749. [on-line], Luxembourg, Office for Official Publications of the European Communities, c2008, [cit. $15^{\text {th }}$ September, 2008], $<$ http://eur-lex.europa.eu/LexUriServ/LexUriServ.do?uri=CELEX: 62005J0166:EN:html> 
Nerudová, D. - David, P.: Empirical Study of Specific Value Added Tax Problems in Selected European Union Member States.

[4] Eur-lex (2006): Council Directive 2006/112/EC of 28 November 2006 on the common system of value added tax. [on-line]. Luxembourg, Office for Official Publications of the European Communities, c2008, [cit. $10^{\text {th }}$ September, 2008], $<$ http://eurlex.europa.eu/LexUriServ/LexUriServ.do?uri=OJ:L:2006: 347:0001:01:EN:html>.

[5] Eur-lex (2008a): Council Directive 2008/8/EC of 12 February 2008 amending Directive 2006/112/EC as regards the place of supply of services. [on-line], Luxembourg, Office for Official Publications of the European Communities, c2008, [cit. $8^{\text {th }}$ September, 2008], $<$ http://eurlex.europa.eu/LexUriServ/LexUriServ.do?uri=OJ:L:2008: 044:0011:01:EN:html>.

[6] Eur-lex (2008b): Council Directive 2008/9/EC of 12 February 2008 laying down detailed rules for the refund of value added tax, provided for in Directive 2006/112/EC, to taxable persons not established in the Member State of refund but established in another Member State. [on-line], Luxembourg, Office for Official Publications of the European Communities, c2008, [cit. $5^{\text {th }}$ September, 2008],

$<$ http://eurlex.europa.eu/LexUriServ/LexUriServ.do?uri=OJ:L:2008: 044:0023:01:EN:html>.

[7] Eur-lex (2008c): Council Regulation (EC) No 143/2008 of 12 February 2008 amending Regulation (EC) No 1798/2003 as regards the introduction of administrative cooperation and the exchange of information concerning the rules relating to the place of supply of services, the special schemes and the refund procedure for value added tax. [on-line], Luxembourg, Office for Official Publications of the European Communities, c2008, [cit. $5^{\text {th }}$ September, 2008], $<$ http://eurlex.europa.eu/LexUriServ/LexUriServ.do?uri=OJ:L:2008: 044:0001:01:EN:html>.

[8] Kubátová, K. (2006): Tax Theory and Policy (in Czech: Daňová teorie a politika). Praha, ASPI, 2006.

[9] Nerudová, D. (2008): Harmonization of tax systems in European Union (in Czech: Harmonizace daňových systémů zemi Evropské unie.) Praha, ASPI, 2008.

[10] Široký, J. (2007): Taxes in European Union (in Czech: Daně v Evropské unii.) Praha, Linde, 2007.

[11] Thurston, M. (1963): Neumark report. Amsterdam, IBFD, 1963. 


\title{
Empirical Study of Specific Value Added Tax Problems in Selected European Union Member States
}

\author{
Danuše NERUDOVÁ - Petr DAVID
}

\begin{abstract}
Empirical study of specific value added tax problems in selected EU member states is focused mainly on the field of providing services. Specifically services provided to a person from the same EU member state, which shall provide this service immediately further to a customer from other EU member state and further provision of service provided by a provider from one EU member state to a recipient of service from other EU member state are concerned and also these services are connected with immovable property situated in the state of provider of service. These issues are solved in the frame of selected EU states - Czech Republic, Slovakia, Hungary and United Kingdom. The results show insufficiencies in treatment of the mentioned field of value added tax not only at the EU level, but also at the national level of the selected states and application of objective provisions in practice as well. General recommendations of process of elimination of insufficiencies causing problems in providing service further or providing service connected with immovable property are here on this base laid down. Except above mentioned facts, this paper also offers wider view on the harmonization process in the field of value added tax in the EU and highlights the significance of value added tax in the general consequences.
\end{abstract}

Key words: VAT; Services provided further; Services connected with immovable property.

JEL classification: H25. 